\title{
Respons Bibit Bud Chips Batang Atas, Tengah, dan Bawah Tebu (Saccharum officinarum L.) terhadap Aplikasi Dosis Mulsa Bagasse
}

\section{(Response of Sugarcane [Saccharum officinarum L.] Seedlings from Top, Middle, and Bottom Bud Chips towards Rate of Bagasse Mulch Application)}

\author{
Silviana Irianti ${ }^{1 *}$, Wiwik Indrawati ${ }^{2}$, Any Kususmastuti ${ }^{2)}$ \\ ${ }^{1)}$ Program Studi Produksi dan Manajemen Industri Perkebunan Politeknik Negeri Lampung dan ${ }^{2)}$ \\ Jurusan Budidaya Tanaman Perkebunan Politeknik Negeri Lampung, Jl. Soekarno-Hatta No. 10 \\ Rajabasa, Bandar Lampung, 35144 \\ E-mail:wiwik@polinela.ac.id
}

\begin{abstract}
There are many benefits of sugarcane (Saccharum officinarum L.) as a sugar source to fulfil human staples food. The use of sugarcane bud chips is one of cultivation technology in order to achieve national sugar self-sufficiency program. Bagasse mulch kept soil moisture and increased organic matter in the soil thathas positive impact on sugarcne growth. The experiment was conducted in Teaching Farm of the State Polytechnic of Lampung, from November 2015 until April 2016. The experiment used Randomized Block Design (RBD) in factorial pattern, consisting of two factors. The first factor is the treatment of bud chips position consisting of 3 levels i.e. top bud chip, middle bud chip, and bottom bud chips. The second factor is the bagasse mulch treatment consisting of 4 levels i.e. control, 3 ton.ha $a^{-1}, 6$ ton.ha ${ }^{-1}$, and 9 ton. $h a^{-1}$. The objectives of the study were to obtain optimal growth among bud chips, optimal bagasse mulch, and to know the interaction between the bud chips position and the bagasse treatments. The results showed that the top bud chips were better than middle bud chips and bottom bud chips. The optimal rate of bagasse mulch was 3 ton.hal. ${ }^{-1}$. There was an interaction between the treatment of sugarcane bud chips and mulch bagasse on leaf length and soil moisture growth.
\end{abstract}

Keywords: bagasse mulch, bud chips, sugarcane seedlings

Diterima: 11 November 2016 / Disetujui: 25 Maret 2017 / Diterbitkan: 3 Mei 2017

\section{PENDAHULUAN}

Tanaman tebu (Saccharum officinarum L.) sebagai penghasil gula, mempunyai manfaat yang sangat besar bagi pemenuhan bahan pokok manusia. Konsumsi gula pasir terus meningkat tiap tahun, tetapi di pihak lain industri gula belum mampu memenuhi permintaan masyarakat. Hal ini terjadi karena peningkatan pendapatan penduduk dan bertambahnya industri pangan membutuhkan bahan baku berupa gula. Defisit gula Indonesia untuk memenuhi kebutuhan konsumsi gula nasional mulai dirasakan sejak tahun 1967. Defisit ini terus meningkat dan hanya bisa dipenuhi melalui impor gula. 
Dari kompilasi taksasi Maret 2014 dari seluruh pabrik gula, diperkirakan luas areal budidaya tebu di Indonesia mencapai 472.792 ha, jumlah tebu yang digiling 26.182.325 ton, dan gula yang dihasilkan lebih kurang 2.927.486 ton. Sedangkan produktivitas tebu yang diproyeksikan 76,5 ton.ha ${ }^{-1,}$ adapun pasar gula Indonesia secara total adalah 5,7 juta ton, yaitu 3,0 juta ton untuk pasar konsumsi dan 2,7 juta ton untuk pasar industri makanan dan minuman. Dari proyeksi Maret 2014 tergambar bahwa kebutuhan gula dalam negeri masih kurang (Yunitasari et al., 2016).

Permasalahan kekurangan akan suplai gula yang terjadi saat ini disebabkan karena produksi tebu yang tidak menunjukkan pengaruh yang nyata terhadap kebutuhan gula, yang dikarenakan tingkat produktivitas tebu yang cendrung masih rendah. Faktor yang dapat menyebabkan tidak optimalnya suatu produktivitas tanaman yaitu sistem pengolahan tanah yang buruk, penggunaan bibit dan benih yang tidak terjamin secara kualitas dan kuantitas, sistem pemupukan yang belum memenuhi standar, kebutuhan akan air untuk irigasi yang tidak terpenuhi dan pengelolaan terhadap hama dan penyakit yang tidak terpadu.

Penggunaan benih unggul tebu dengan pembibitan bud chips terus dikembangkan pada tingkat penangkar Kebun Benih Datar (KBD) dan petani pengembang untuk memenuhi permintaan bibit dalam mendukung program bongkar ratoon dan tanam tebu baru (plant cane). Penggunaan benih unggul tebu bud chips dalam 1 hektar (KBD) menghasilkan benih 50-60 ton setara 350.000 - 420.000 mata tunas bud chips. Kebutuhan bibit bud chips dalam satu hektar pertanaman PC diperlukan 12.000-18.000 batang bibit setara 2-2,5 ton bagal. Sehingga dalam 1 ha luasan (KBD) mampu memenuhi kebutuhan areal tanam baru/PC mencapai 29-35 ha. Pembuatan kebun bibit datar memerlukan biaya besar, dengan penggunaan bibit tebu bud chips ini lebih efisien dan mampu menekan luas areal (KBD) mencapai 75-80\%.

Penggunaan bahan tanam tebu bud chips merupakan penerapan teknologi budidaya tebu dalam upaya pencapaian program swasembada gula nasional. Pertumbuhan tanaman tebu sejak awal tumbuh seragam menjadikan tingkat kemasakan tebu di lapang sama mampu meningkatkan rendemen dan produksi persatuan luas tanam (Prayogo et al., 2016).

Mulsa merupakan suatu material penutup tanaman budidaya untuk menjaga kelembaban tanah serta menekan pertumbuhan gulma dan penyakit sehingga membuat tanaman tersebut tumbuh dengan baik. Mulsa dapat digolongkan menjadi dua berdasarkan materialnya yaitu mulsa organik dan mulsa anorganik. Mulsa organik berasal dari bahan-bahan alami yang mudah terurai seperti sisa-sisa tanaman seperti jerami dan alang-alang. Mulsa organik diberikan setelah tanaman atau bibit ditanam. Keuntungan mulsa ini adalah lebih ekonomis, mudah diperoleh, dan dapat terurai sehingga menambah kandungan bahan organik pada tanah (Kusmayadi, 2014). Mulsa anorganik terbuat dari bahan-bahan sintetis yang sukar/tidak dapat terurai. Contoh mulsa anorganik adalah mulsa plastik, mulsa plastik hitam perak atau karung. Mulsa ini dipasang sebelum tanaman/bibit ditanam, lalu dilubangi sesuai dengan jarak tanam. 
Pemberian mulsa memiliki keuntungan dapat meningkatkan aktivitas jasad renik (mikroorganisme tanah), sehingga memperbaiki sifat fisika dan kimia tanah (Soekardi, 1986). Dekomposisi mulsa serasah tebu akan berpengaruh terhadap kesuburan kimia tanah. Serasah tebu mengandung $0,3-0,4 \% \mathrm{~N} ; 0,1-0,13 \% \mathrm{P} ; 0.6 \% \mathrm{~K}$ dan $42-46 \%$ bahan organik. Kesuburan fisika tanah akan mengalami perubahan pola karena dekomposisi mulsa serasah meningkatkan bahan organik tanah, aktivitas biologi, memperbaiki aerasi, dan meningkatkan infiltrasi. Mulsa juga akan membantu mencegah erosi. Sisa produksi tanaman tebu yaitu limbah padat berupa ampas tebu (bagasse), endapan nira yang disebut blotong (filter cake) dan sisa bahan bakar uap yang disebut abu. Bagasse dapat dimanfaatkan sebagai mulsa (Batubara et al., 2013; Swibawa et al., 2015). Selain itu, bagasse, blotong, dan abu dapat dimanfaatkan sebagai bahan baku pembuatan kompos yang dapat digunakan sebagai bahan penyubur tanah (Ismayana et al., 2012).

\section{METODE PENELITIAN}

Penelitian ini dilaksanakan di kebun penelitian Politeknik Negeri Lampung pada bulan November sampai dengan April 2016. Bahan yang digunakan dalam penelitian ini adalah bibit tebu bud chips varietas GM3 yang diperoleh dari kebun petani Mitra GMP, pupuk Urea, TSP, KCL, dan bagasse. Alat yang digunakan cangkul, golok, rol meter, penggaris, ember, timbangan, gembor,soil tester, klorofil meter.

\section{Rancangan Percobaan}

Penelitian ini menggunakan rancangan perlakuan pola faktorial $3 \times 4$ dalam Rancangan Acak Kelompok (RAK) dengan tiga ulangan. Faktor pertama yang digunakan adalah posisi bud chips (B) terdiri atas 3 taraf yaitu $\mathrm{B}_{1}$ (bud chips atas), $\mathrm{B}_{2}$ (bud chips tengah), dan $\mathrm{B}_{3}$ (bud chips bawah). Faktor yang kedua yaitu dosis mulsa baggase digunakan (D) terdiri dari 4 taraf yaitu $\mathrm{D}_{0}$ (kontrol), $\mathrm{D}_{1}$ (3 ton.ha ${ }^{-1}$ (setara dengan 0,78 kg.2 meter kairan ${ }^{-1}$ bagasse), $\mathrm{D}_{2}\left(6\right.$ ton.ha ${ }^{-1}$ setara dengan 1,56 kg.2 meter kairan ${ }^{-1}$ bagasse $)$, dan $\mathrm{D}_{3}\left(9\right.$ ton.ha ${ }^{-1}$ setara dengan 2,34 kg.2 meter kairan ${ }^{-1}$ bagasse $)$.

\section{Prosedur Penelitian}

Kairan dibuat dengan panjang $2 \mathrm{~m}$, lebar $30 \mathrm{~cm}$, dan jarak antarkairan 1,3 m. Bibit bud chips tebu yang digunakan dalam penelitian ini berumur 8 bulan. Bibiit bud chips tebu bagian atas, tengah, dan bawah ditentukan berdasarkan banyaknya ruas tebu dibagi 3. Pengambil mata tunas tebu sebagai bahan tanam dilakukan secara manual dengan memotong bibit tebu $10 \mathrm{~cm}$ dengan satu mata per bibit. Dosis pupuk yang diberikan yaitu Urea 300 kg.ha ${ }^{-1}$ (setara dengan 40 g.kairan ${ }^{-1}$ ), TSP 200 kg.ha ${ }^{-1}$ (setara dengan 26 g.kairan ${ }^{-1}$ ), KCl 300 kg.ha ${ }^{-1}$ (setara dengan 30 g.kairan ${ }^{-1}$ ). Pupuk akan diaplikasikan dua kali, aplikasi pertama bersamaan saat tanam sebanyak 1/3 dosis dan aplikasi ke dua umur 1,5 bulan sebanyak $2 / 3$ dari dosis yang diberikan. 
Penanaman bibit bud chips tebu dilakukan dengan metode line spacing dengan jarak antar bibit $10 \mathrm{~cm}$. Baggase yang digunakan sebagai mulsa dalam penelitian ini diaplikasikan saat awal tanam. Bagasse diaplikasikan pada permukaan kairan yang telah ditanami bibit bud chips tebu. Penyiraman dilakukan sehari sekali yaitu pada sore hari atau disesuaikan dengan kondisi di lapangan.

\section{Pengamatan}

Pengamatan dilaksanakan setiap 2 minggu setelah tanaman berumur 1 bulan setelah tanam (BST), kecuali pada variabel kandungan klorofil. Pengamatan dihentikan ketika fase pertumbuhan anakan selesai (umur 5 BST). Variabel yang diamati antara lain:

1. Tinggi tanaman. Pengukuran tinggi tanaman dilakukan pada tanaman umur 1 BST sampai dengan 5 BST. Pengukuran tinggi tanaman dengan menggunakan penggaris dengan cara mengukur tinggi batang tanaman induk dari permukaan tanah sampai ruas teratas (titik tumbuh).

2. Panjang daun. Panjang daun diukur dengan menggunakan meteran atau penggaris dimuai dari pangkal pelepah hingga ujung daun pada daun terpanjang batang utama. Pengukuran panjang daun dimulai pada tanaman umur 1 BST.

3. Luas daun. Luas daun diukur dengan menghitung $\mathrm{p} \times 1$ (panjang $\times$ lebar) pada daun terpanjang batang utama menggunakan meteran atau penggaris. Pengukuran panjang daun dilakukan setelah tanaman umur 1 BST dan diukur setiap 2 minggu sekali.

4. Jumlah anakan. Jumlah anakan dihitung sebagai anakan yang muncul dari tanaman induk.

5. Diameter batang. Pengukuran diameter batang dilakukan pada ketinggian $10 \mathrm{~cm}$ dari permukaan tanah menggunakan jangka sorong.

6. Kelembaban tanah. Pengukuran kelembaban tanah dilakukan dengan menggunakan soil tester.

7. Kandungan klorofil. Pengukuran jumlah klorofil dilakukan setiap bulan dimulai pada tanaman umur 2 BST sampai dengan 5 BST menggunakan klorofil meter tipe SPAD 502.

\section{HASIL DAN PEMBAHASAN}

\section{Tinggi Tanaman}

Hasil uji sidik ragam tinggi tanaman pada perlakuan posisi bud chips dan dosis mulsa bagasse berbeda nyata, dan tidak terjadi interaksi secara nyata. Rerata pengaruh tunggal perlakuan posisi bud chips dan dosis mulsa bagasse terhadap tinggi tanaman tebu tertera pada Tabel 1.

Tabel 1 menunjukkan bahwa tinggi tanaman tebu pada perlakuan posisi bud chips atas berbeda nyata dengan bud chips tengah dan bawah. Hal ini diduga adanya faktor internal sifat genetik yaitu hormon yang ada didalam tubuh tanaman yang mempengaruhi pertumbuhan tinggi tanaman. 
Tabel 1. Rerata pengaruh tunggal pada perlakuan posisi bud chips dan dosis mulsa bagasse terhadap tinggi tanaman tebu $(\mathrm{cm}) 18$ MST

\begin{tabular}{|c|c|}
\hline Perlakuan & Rerata tinggi tanaman \\
\hline $\mathrm{B}_{1}$ (bud chips atas) & $287,20 \mathrm{~b}$ \\
\hline $\mathrm{B}_{2}$ (bud chips tengah) & $267,52 \mathrm{a}$ \\
\hline $\mathrm{B}_{3}$ (bud chips bawah) & $259,40 \mathrm{a}$ \\
\hline BNT 0,05 & 11,41 \\
\hline$\overline{\mathrm{D}_{0} \text { (kontrol) }}$ & $244,81 \mathrm{a}$ \\
\hline $\mathrm{D}_{1}\left(3\right.$ ton $\left.\mathrm{ha}^{-1}\right)$ & $282,58 \mathrm{c}$ \\
\hline $\mathrm{D}_{2}\left(6\right.$ ton.ha $\left.{ }^{-1}\right)$ & $282,37 \mathrm{c}$ \\
\hline $\mathrm{D}_{3}\left(9\right.$ ton $\left.\mathrm{ha}^{-1}\right)$ & $275,73 \mathrm{~b}$ \\
\hline BNT 0,05 & 8,55 \\
\hline
\end{tabular}

Keterangan: Rerata pada kolom yang sama diikuti oleh huruf yang tidak sama beda nyata dengan uji BNT pada tingkat ketelitian 95\%

Secara alami, dalam tubuh tanaman sudah memproduksi hormon seperti auksin yang berperan penting dalam pertumbuhan tanaman. Secara fisiologi auksin mempercepat pemanjangan dan pembesaran sel. Umumnya hormon tersebut diproduksi pada jaringan maristem yang aktif yang terdapat pada batang atas kemudian menyebar keseluruh tubuh tumbuhan melalui jaringan floem atau parenkim (Fu \& Wang, 2011).

Selain adanya faktor imternal yang terdapat dalam tubuh tanaman, faktor eksternal sinar matahari juga dapat mempengaruhi pertumbuhan tanaman tebu. Pengaruh intensitas cahaya matahari erat kaitannya dengan kandungan hormon dalam jaringan tanaman (Song \& Banyo, 2011; Hamdani et al., 2016). Komponen organik tersebut diproduksi pada meristem terminal dan translokasi secara basipetal, yang akan memberikan pengaruh terhadap proses yang akan digunakan oleh hormon.

Tinggi tanaman pada perlakuan dosis mulsa bagasse 3 ton.ha ${ }^{-1}$ dan 6 ton.ha ${ }^{-1}$ lebih tinggi dibandingkan dengan perlakuan dosis mulsa bagasse 9 ton.ha ${ }^{-1}$ dan kontrol. Hal ini diduga mulsa bagasse yang diberikan telah mencukupi kebutuhan hara makro bagi tanaman. Unsur hara yang tersedia dengan jumlah yang cukup dan seimbang, dapat meningkatkan pertumbuhan tanaman. Namun, perlakuan dosis mulsa bagasse 9 ton.ha $^{-1}$ memberikan hasil yang lebih rendah dibandingkan dengan dosis mulsa bagasse 3 ton.ha ${ }^{-1}$ dan 6 ton.ha ${ }^{-1}$. Hal tersebut diduga proses pelapukan bagasse tidak terjadi secara optimal dikarenakan ketebalan lapisan mulsa dan pengaruh iklim (curah hujan, sinar matahari, jasad renik dan mikro organisme), sehingga bahan organik pada lapisan bagasse yang terdapat pada sekitar serabut akar tidak terserap secara optimal (Windusari et al., 2013; Alfian \& Susanti, 2013). 


\section{Panjang Daun}

Hasil uji sidik ragam panjang daun pada perlakuan posisi bud chips dan dosis mulsa bagasse berbeda nyata, dan terjadi interaksi secara nyata. Rerata interaksi perlakuan posisi bud chips dan dosis mulsa bagasse terhadap panjang daun tertera pada Tabel 2.

Tabel 2. Rerata interaksi pada perlakuan posisi bud chips dan dosis mulsa bagasse terhadap panjang daun $(\mathrm{cm}) 18 \mathrm{MST}$

\begin{tabular}{|c|c|c|c|c|c|}
\hline \multirow{3}{*}{ Bud chips (B) } & \multicolumn{5}{|c|}{ Perlakuan Dosis Mulsa Baggase (D) } \\
\hline & $\mathrm{D}_{0}$ & $\mathrm{D}_{1}$ & $\mathrm{D}_{2}$ & $\mathrm{D}_{3}$ & Rerata (h) \\
\hline & 0 & $\left(3\right.$ ton.ha $\left.a^{-1}\right)$ & $\left(6\right.$ ton.ha $\left.{ }^{-1}\right)$ & $\left(9\right.$ ton.ha $\left.a^{-1}\right)$ & Mulata $(1)$ \\
\hline $\mathrm{B}_{1}$ (bud chips atas) & $153,13 \mathrm{a}$ & $179,50 \mathrm{~d}$ & $165,63 \mathrm{c}$ & $165,43 \mathrm{c}$ & $165,92 \mathrm{~b}$ \\
\hline $\mathrm{B}_{2}$ (bud chips tengah) & $150,23 a$ & $155,47 b$ & $156,53 b$ & 153,20 a & $153,85 \mathrm{a}$ \\
\hline $\mathrm{B}_{3}$ (bud chips bawah) & $148,87 \mathrm{a}$ & $151,17 \mathrm{a}$ & $152,20 \mathrm{a}$ & 152,60 a & $151,21 \mathrm{a}$ \\
\hline Rerata (d) & $150,74 \mathrm{a}$ & $162,04 b$ & $158,12 b$ & $157,07 \mathrm{~b}$ & \\
\hline BNT 0,05 & 5,35 & & & & \\
\hline
\end{tabular}

Keterangan: Rerata pada kolom dan baris yang sama diikuti oleh huruf yang tidak sama beda nyata dengan uji BNT pada tingkat ketelitian 95\%

Tabel 2 menunjukkan bahwa panjang daun pada interaksi perlakuan posisi bud chips atas dan pemberian dosis mulsa bagasse 3 ton.ha ${ }^{-1}$ memberi pengaruh panjang daun yang optimal, sedangkan pada interaksi perlakuan posisi bud chips bawah dan perlakuan tanpa pemberian mulsa bagasse memberikan pertumbuhan panjang daun yang paling rendah. Hal ini diduga perlakuan posisi bud chips bagian atas masih terdapat sel-sel aktif yang membelah, menghasilkan hormon yang mempengaruhi pertumbuhan (Patar et al., 2015).

Perlakuan mulsa bagasse akan meningkatkan bahan organik dan hara tanah, sehingga berdampak positif terhadap pertumbuhan tebu. Tanaman tebu dalam proses pembentukan perpanjangan daun membutuhkan unsur hara nitrogen, sehingga pada perlakuan tanpa mulsa bagasse tidak terdapat bahan organik dan unsur hara yang cukup dan mengakibatkan pertumbuhan pada panjang daun lebih rendah (Cahyani et al., 2016).

Adanya hormon dari perlakuan posisi bud chips bagian atas yang berpengaruh pada pertumbuhan tanaman, dan pemberian dosis mulsa bagasse 3 ton.ha ${ }^{-1}$ akan meningkatkan ketersediaan hara pada tanah. Sehingga saling bersinergi untuk menghasilkan panjang daun yang lebih tinggi dibandingkan perlakuan posisi bud chips bagian bawah yang lebih rendah pertumbuhannya dan tanpa pemberian mulsa bagasse yang menyebabkan hara tersedia pada tanah tidak tercukupi, sehingga pertumbuhan perlakuan posisi bud chips bagian bawah dan tanpa perlakuan mulsa bagasse (kontrol) pertumbuhan panjang daunnya lebih rendah (Putra et al., 2016). 


\section{Luas Daun}

Hasil uji sidik ragam luas daun pada perlakuan posisi bud chips tidak berbeda nyata, sedangkan pada perlakuan dosis mulsa bagasse berbeda nyata, dan tidak terjadi interaksi secara nyata. Rerata pengaruh tunggal perlakuan posisi bud chips dan dosis mulsa bagasse terhadap luas daun tertera pada Tabel 3.

Tabel 3. Rerata pengaruh tunggal pada perlakuan posisi bud chips dan dosis mulsa bagasse terhadap luas daun $(\mathrm{cm}) 18$ MST

\begin{tabular}{|c|c|}
\hline Perlakuan & Rerata luas daun \\
\hline $\mathrm{B}_{1}$ (bud chips atas) & $566,89 \mathrm{a}$ \\
\hline $\mathrm{B}_{2}$ (bud chips tengah) & $554,99 \mathrm{a}$ \\
\hline $\mathrm{B}_{3}$ (bud chips bawah) & 536,36 a \\
\hline BNT 0,05 & 30,76 \\
\hline $\mathrm{D}_{0}$ (kontrol) & 459,78 a \\
\hline $\mathrm{D}_{1}\left(3\right.$ ton. $\left.^{-1} \mathrm{a}^{-1}\right)$ & $603,52 \mathrm{c}$ \\
\hline $\mathrm{D}_{2}\left(6\right.$ ton.ha $\left.^{-1}\right)$ & $580,51 \mathrm{bc}$ \\
\hline $\mathrm{D}_{3}\left(9\right.$ ton $\left.\mathrm{ha}^{-1}\right)$ & $567,17 \mathrm{~b}$ \\
\hline BNT 0,05 & 23,07 \\
\hline
\end{tabular}

Keterangan: Rerata pada kolom yang sama diikuti oleh huruf yang tidak sama beda nyata dengan uji BNT pada tingkat ketelitian 95\%

Tabel 3 menunjukkan bahwa luas daun pada perlakuan posisi bud chips atas, tengah dan bawah tidak berbeda nyata. Hal ini diduga bahwa proses pertumbuhan luas daun terjadi karena adanya faktor genetik dan adanya faktor eksternal yang dihasilkan dari luar. Faktor genetik yang terjadi karena adanya hormon yang dihasilkan oleh tumbuhan sendiri (hormon endogen) auksin yang dapat mempercepat pemanjangan sel pertumbuhan luas daun tanaman. Sedangkan faktor eksternal yang terjadi adanya penyerepan cahaya matahari sehingga menghasilkan jumlah daun yang banyak, luas daun besar dan memperluas permukaan yang tersedia untuk fotosintesis (Pantilu, et al., 2012).

Luas daun pada perlakuan dosis mulsa bagasse 3 ton.ha ${ }^{-1}$ berbeda nyata dengan perlakuan dosis mulsa bagasse 6 ton.ha ${ }^{-1}, 9$ ton.ha ${ }^{-1}$ dan kontrol. Hal ini diduga bahwa pada proses pertumbuhan, tanaman mampu memanfaatkan faktor-faktor tumbuh disekelilingnya baik yang berada di bawah permukaan tanah maupun yang berada di atas permukaan tanah (Nurmawati et al., 2001).

Ketersedian unsur hara bagi pertumbuhan luas daun dapat terpenuhi dengan pemberian dosis mulsa bagasse 3 ton.ha ${ }^{-1}$, namun pemberian mulsa baggase yang lebih tinggi akan berdampak terbalik dengan pemberian dosis mulsa bagasse 3 ton.ha ${ }^{-1}$. Sedangkan tanaman yang tidak diberi 
perlakuan mulsa baggase unsur $\mathrm{N}$ yang tersedia kurang mencukupi sehingga tanaman memiliki luas daun yang lebih rendah dibandingkan dengan adanya perlakuan mulsa bagasse.

\section{Jumlah Anakan}

Hasil uji sidik ragam jumlah anakan pada perlakuan posisi bud chips dan dosis mulsa bagasse berbeda nyata, dan tidak terjadi interaksi secara nyata. Rerata pengaruh tunggal perlakuan posisi bud chips dan dosis mulsa bagasse terhadap jumlah anakan tertera pada Tabel 4.

Tabel 4. Rerata pengaruh tunggal pada perlakuan posisi bud chips dan dosis mulsa bagasse terhadap jumlah anakan (batang) 18 MST

\begin{tabular}{|c|c|}
\hline Perlakuan & Rerata jumlah anakan \\
\hline$\overline{\mathrm{B}_{1} \text { (bud chips atas) }}$ & $1,83 \mathrm{c}$ \\
\hline $\mathrm{B}_{2}$ (bud chips tengah) & $1,64 \mathrm{~b}$ \\
\hline $\mathrm{B}_{3}$ (bud chips bawah) & $1,59 \mathrm{a}$ \\
\hline BNT 0,05 & 0,04 \\
\hline $\mathrm{D}_{0}$ (kontrol) & $1,61 \mathrm{a}$ \\
\hline $\mathrm{D}_{1}\left(3\right.$ ton.ha $\left.^{-1}\right)$ & $1,84 \mathrm{c}$ \\
\hline $\mathrm{D}_{2}\left(6\right.$ ton.ha $\left.\mathrm{A}^{-1}\right)$ & $1,74 \mathrm{~b}$ \\
\hline $\mathrm{D}_{3}\left(9\right.$ ton.ha $\left.^{-1}\right)$ & $1,76 \mathrm{~b}$ \\
\hline BNT 0,05 & 0,03 \\
\hline
\end{tabular}

Keterangan: Rerata pada kolom yang sama diikuti oleh huruf yang tidak sama beda nyata dengan uji BNT pada tingkat ketelitian 95\%

Tabel 4 menunjukkan bahwa jumlah anakan pada perlakuan posisi bud chips atas, berbeda nyata dengan perlakuan bud chip tengah dan bawah. Hal ini diduga bahwa stek yang berasal dari batang atas merupakan bagian tumbuhan yang sel-selnya masih aktif membelah dan menghasilkan hormon, sehingga posisi bud chips bagian atas yang ditanam lebih cepat tumbuh tunasnya. Ujung paling atas suatu batang tebu terdiri dari titik tumbuh yang tertutup oleh daun-daun termuda (Sukmadjaja et al., 2016). Titik tumbuh terdiri dari suatu maristem tipis, yang sel-selnya dalam keadaan melakukan proses pembelahan aktif. Hormon dihasilkan terutama pada bagian sel-sel yang masih akti membelah. Hormon dapat mempengaruhi pertumbuhan dan perkembangan tanaman.

Jumlah anakan tertinggi pada perlakuan dosis mulsa bagasse 3 ton.ha ${ }^{-1}$. Hal ini diduga mulsa bagasse yang diberikan telah mencukupi kebutuhan hara makro bagi tanaman. Unsur hara yang tersedia dengan jumlah yang cukup dan seimbang, dapat meningkatkan pertumbuhan tanaman. Pemberian mulsa bagasse akan memberikan suatu lingkungan pertumbuhan yang baik bagi tanaman karena dapat mengurangi evaporasi, mencegah penyinaran langsung sinar matahari yang berlebihan terhadap tanah serta kelembaban tanah dapat terjaga, sehingga tanaman dapat 
menyerap air dan unsur hara dengan baik. Perbedaan penggunaan dosis mulsa bagasse yang diberikan memberikan pengaruh yang berbeda pada pertumbuhan jumlah anakan.

\section{Diameter Batang}

Hasil uji sidik ragam diameter batang pada perlakuan posisi bud chips dan dosis mulsa bagasse berbeda nyata, dan tidak terjadi interaksi secara nyata. Rerata pengaruh tunggal perlakuan posisi bud chips dan dosis mulsa bagasse terhadap diameter batang tertera pada Tabel 5 .

Tabel 5. Rerata pengaruh tunggal pada perlakuan posisi bud chips dan dosis mulsa bagasse terhadap diameter batang $(\mathrm{cm}) 18$ MST

\begin{tabular}{|c|c|}
\hline Perlakuan & $\begin{array}{c}\text { Rerata diameter } \\
\text { batang }\end{array}$ \\
\hline $\mathrm{B}_{1}$ (bud chips atas) & $1,99 \mathrm{~b}$ \\
\hline $\mathrm{B}_{2}$ (bud chips tengah) & $1,93 \mathrm{a}$ \\
\hline $\mathrm{B}_{3}$ (bud chips bawah) & $1,93 \mathrm{a}$ \\
\hline BNT 0,05 & 0,04 \\
\hline $\mathrm{D}_{0}$ (kontrol) & $1,89 \mathrm{a}$ \\
\hline $\mathrm{D}_{1}\left(3\right.$ ton. $\left.\mathrm{ha}^{-1}\right)$ & $1,99 \mathrm{c}$ \\
\hline $\mathrm{D}_{2}\left(6\right.$ ton.ha $\left.{ }^{-1}\right)$ & $1,96 \mathrm{~b}$ \\
\hline $\mathrm{D}_{3}\left(9\right.$ ton.ha $\left.{ }^{-1}\right)$ & $1,96 \mathrm{a}$ \\
\hline BNT 0,05 & 0,03 \\
\hline
\end{tabular}

Keterangan: Rerata pada kolom yang sama diikuti oleh huruf yang tidak sama beda nyata dengan uji BNT pada tingkat ketelitian 95\%

Tabel 5 menunjukkan bahwa diameter batang pada perlakuan posisi bud chips atas, berbeda nyata dengan perlakuan posisi bud chip tengah dan bud chip bawah. Hal ini diduga perlakuan posisi bud chips yang berasal dari batang atas lebih tinggi kandungan hormon tumbuh dibandingkan dengan posisi bud chips yang berasal dari batang tengah dan bawah.

Stek bud chips batang atas merupakan bagian yang paling banyak mengandung hormon tumbuh salah satunya auksin. Hormon auksin berperan mempercepat pemanjangan sel, sehingga hormon auksin dapat membantu proses pertumbuhan dan perkembangan diameter batang. batang. Stek posisi bud chips bagian tengah dan bawah memiliki hormon auksin lebih sedikit, sehingga pertumbuhan tinggi batang pada stek posisi bud chips bagian bawah lebih rendah dibandingkan stek posisi bud chips yang berasal dari batang atas, hal ini diduga dari hasil penelitian (Putri et al., 2013).

Diameter batang pada perlakuan dosis mulsa baggase 3 ton.ha ${ }^{-1}$ lebih tinggi dibandingkan anatara perlakuan mulsa baggase 6 ton.ha ${ }^{-1}, 9$ ton.ha ${ }^{-1}$, dan kontrol. Hal ini diduga perlakuan mulsa baggase 3 ton.ha ${ }^{-1}$ telah meningkatkan ketersediaan hara tanah seningga pertumbuhan luas daun 
berlangsung optimal, sedangkan perlakuan mulsa baggase yang lebih tinggi dapat menyebabkan pertumbuhan yang lebih rendah.

Perlakuan mulsa baggase akan meningkatkan ketersediaan bahan organik dan unsur hara makro di dalam tanah, sehingga berdampak positif terhadap pertumbuhan tebu. Tanaman tebu, sangat memerlukan unsur nitrogen yang digunakan untuk pembentukan batang dan daun sehingga pada perlakuan yang tidak diberikan nitrogen akan menyebabkan penurunan pada diameter batang (Desiana et al., 2013; Arif et al., 2014).

\section{Kelembaban Tanah}

Hasil uji sidik ragam kelembaban pada perlakuan posisi bud chips dan dosis mulsa bagasse berbeda nyata, dan terjadi interaksi secara nyata. Rerata interaksi perlakuan posisi bud chips dan dosis mulsa bagasse terhadap kelembaban tanah tertera pada Tabel 6.

Tabel 6. Rerata interaksi pada perlakuan posisi bud chips dan dosis mulsa bagasse terhadap kelembaban tanah (persen) 18 MST

\begin{tabular}{lccccc}
\hline \multirow{2}{*}{ Bud chips (B) } & \multicolumn{5}{c}{ Perlakuan Dosis Mulsa Baggase (D) } \\
\cline { 2 - 6 } & $\mathrm{D}_{0}$ & $\mathrm{D}_{1}$ & $\mathrm{D}_{2}$ & $\mathrm{D}_{3}$ & Rerata \\
& 0 & $\left(3\right.$ ton.ha $\left.^{-1}\right)$ & $\left(6\right.$ ton.ha $\left.^{-1}\right)$ & $\left(9\right.$ ton.ha $\left.^{-1}\right)$ & $(\mathrm{b})$ \\
\hline $\mathrm{B}_{1}$ (bud chips atas) & $40,00 \mathrm{a}$ & $48,33 \mathrm{de}$ & $50,00 \mathrm{a}$ & $51,66 \mathrm{f}$ & $47,50 \mathrm{~b}$ \\
$\mathrm{~B}_{2}$ (bud chips tengah) & $41,66 \mathrm{a}$ & $46,66 \mathrm{~d}$ & $46,66 \mathrm{~d}$ & $45,00 \mathrm{c}$ & $45,00 \mathrm{a}$ \\
$\mathrm{B}_{3}$ (bud chips bawah) & $43,33 \mathrm{~b}$ & $46,66 \mathrm{~d}$ & $48,33 \mathrm{de}$ & $45,00 \mathrm{c}$ & $45,83 \mathrm{a}$ \\
Rerata (d) & $41,66 \mathrm{a}$ & $47,22 \mathrm{~b}$ & $48,33 \mathrm{~b}$ & $47,22 \mathrm{~b}$ & \\
BNT 0,05 & 2,32 & & & & \\
\hline
\end{tabular}

Keterangan: Rerata pada kolom dan baris yang sama diikuti oleh huruf yang tidak sama beda nyata dengan uji BNT pada tingkat ketelitian 95\%

Tabel 6 menunjukkan bahwa kelembaban tanah pada interaksi perlakuan bud chips atas dan perlakuan mulsa bagasse 9 ton.ha ${ }^{-1}$ mempengaruhi kelembaban tanah lebih tinggi, dibandingkan dengan perlakuan bud chips atas tanpa mulsa bagasse. Hal ini diduga bahwa penggunaan mulsa bagasse dengan jumlah yang besar akan menghalangi proses penyinaran langsung matahari terhadap tanah, sehingga proses evapotranspirasi dapat ditekan dan mengakibatkan suhu di dalam tanah stabil. Secara fisik mulsa mampu menjaga suhu tanah lebih stabil dan mampu mempertahankan kelembaban disekitar perakaran tanaman (Doring et al., 2006).

Hasil penelitian Swibawa (2015) menunjukkan bahwa penggunaan mulsa bagasse mengakibatkan penurunan suhu tanah siang hari yang mampu menekan evapotranspirasi, menurunkan suhu udara dan tanah. Selain itu tanah-tanah yang tidak diberi mulsa cendrung menurunkan kadar bahan organik tanah, sebaliknya pada tanah yang diberi mulsa kandungan bahan organiknya cukup meningkat.

24 Jurnal AIP Volume 5 No. 1 | Mei 2017: 15-28 
Pemberian mulsa organik pada tanah akan pengaruh yang baik bagi perbaikan sifat fisik tanah, meningkatkan penyerapan air tanah, mengurangi kisaran suhu dan dapat mengurangi kisaran suhu tanah dan dapat mengendalikan pertumbuhan gulma, mempertinggi kadar humus tanah dan memperbaiki aerasi dan drainase tanah sehingga akar dapat berkembang dengan baik dan pertumbuhan tanaman akan lebih subur (Prasetyo \& Suriadikarta, 2006).

\section{Kandungan Klorofil}

Hasil uji sidik ragam jumlah klorofil pada perlakuan posisi bud chips dan dosis mulsa bagasse berbeda nyata, dan tidak terjadi interaksi secara nyata. Rerata pengaruh tunggal perlakuan posisi bud chips dan dosis mulsa bagasse terhadap jumlah klorofil tertera pada Tabel 7.

Tabel 7. Rerata pengaruh tunggal pada perlakuan posisi bud chips dan dosis mulsa bagasse terhadap kandungan klorofil 18 MST

\begin{tabular}{|c|c|}
\hline Perlakuan & Rerata kandungan klorofil \\
\hline $\mathrm{B}_{1}$ (bud chips atas) & $45,94 \mathrm{c}$ \\
\hline $\mathrm{B}_{2}$ (bud chips tengah) & $42,38 \mathrm{~b}$ \\
\hline $\mathrm{B}_{3}$ (bud chips bawah) & $40,53 \mathrm{a}$ \\
\hline BNT 0,05 & 1,84 \\
\hline $\mathrm{D}_{0}$ (kontrol) & 40,49 a \\
\hline $\mathrm{D}_{1}\left(3\right.$ ton.ha $\left.{ }^{-1}\right)$ & $44,36 \mathrm{c}$ \\
\hline $\mathrm{D}_{2}\left(6\right.$ ton.ha $\left.{ }^{-1}\right)$ & $41,28 \mathrm{a}$ \\
\hline $\mathrm{D}_{3}\left(9\right.$ ton. ha $\left.\mathrm{a}^{-1}\right)$ & $42,67 \mathrm{~b}$ \\
\hline BNT 0,05 & 0,84 \\
\hline
\end{tabular}

Keterangan: Rerata pada kolom yang sama diikuti oleh huruf yang tidak sama beda nyata dengan uji BNT pada tingkat ketelitian 95\%

Tabel 7 menunjukkan bahwa jumlah klorofil pada perlakuan posisi bud chips lebih tinggi dibandingkan atas tengah dan bawah. Hal ini diduga bahwa proses pembentukan klorofil sangat dipengaruhi oleh ketersediaan unsur hara $\mathrm{N}$ pada batang atas, sehingga memberikan pengaruh ypada perlakuan posisi bud chips atas. Pembentukan klorofil yang baik akan sangat berpengaruh pada proses fotosintesis tanaman. Apabila proses fotosintesis berjalan dengan baik maka fotosintat yang dihasilkan juga semakin meningkat (Lestari, 2009).

Jumlah klorofil pada perlakuan dosis mulsa bagasse 3 ton.ha ${ }^{-1}$ lebih tinggi dibandingkan dengan dosis mulsa bagasse 6 ton.ha ${ }^{-1}, 9$ ton.ha ${ }^{-1}$ dan kontrol. Hal ini diduga pemberian mulsa bagasse belum terdekomposisi. Sesuai dengan pernyataan Sudyastuti \& Setyawan (2007) bahwa semakin banyak pemberian mulsa pada lahan maka diharapkan kemampuan tanah untuk mempertahankan kadar airnya juga semakin tinggi, namun hasil penelitian tidak sesuai dengan 
asumsi. Hal ini diduga karena bagasse tebu sebagai mulsa organik yang diberikan belum terdekomposisi. sehingga pada proses pembentukkan jumlah klorofil mendapatkan hasil yang tidak berbeda antara perlakuan mulsa bagasse dan kontrol.

Mulsa bagasse dapat meningkatkan bahan organik dan unsur hara makro yang mencukupi pada tanah. Bahan organik dan unsur hara yang tercukupi pada tanah dapat membantu proses pertumbuhan dan perkembangan tanaman. Unsur hara makro $\mathrm{N}$ yang terdapat pada mulsa bagasse dapat berperan pada proses fotosintesin yang berlangsung (Fahrurozzi \& Latifah, 2005).

Adanya unsur nitrogen yang banyak di dalam tanaman digunakan oleh daun untuk berfotosintesis. Sehingga menghasilkan jumlah daun yang banyak, luas daun besar dan memperluas permukaan yang tersedia untuk fotosintesis. Apabila proses fotosintesis berjalan dengan baik maka fotosintat yang dihasilkan juga semakin meningkat untuk ditranslokasikan pada bagian tanaman yang lain. Nutrisi yang tercukupi akan mempercepat metabolisme dalam tubuh tanaman seperti sintesis klorofil sehingga laju fotosintesis akan meningkat. Peningkatan laju fotosintesis akan diikuti dengan semakin banyak karbohidrat yang dihasilkan (Prayudyaningsih \& Sari, 2016).

\section{KESIMPULAN DAN SARAN}

\section{Kesimpulan}

Bibit bud chips tebu bagian atas mengalami pertumbuhan yang lebih baik dibandingkan bibit bud chips bagiang tengah dan bawah. Dosis optimal mulsa baggase yang dapat diaplikasikan untuk pertumbuhan bud chips atas, tengah dan bawah tebu adalah dosis 3 ton.ha ${ }^{-1}$. Terdapat interaksi antara perlakuan bud chips tebu dan mulsa baggase pada pertumbuhan panjang daun dan kelembaban tanah.

\section{Saran}

Perlu dilakukan penelitian lanjutan dengan waktu pengamatan sampai akhir masa pertumbuhan generatif untuk persentase nira yang terkandung.

\section{DAFTAR PUSTAKA}

Alfian, R., \& Susanti, H. (2013). Penetapan kadar fenolik total ekstrak metanol kelopak bunga rosella merah (Hibiscus sabdariffa Linn) dengan variasi tempat tumbuh secara spektrofotometri. Pharmaciana, 2(1), 73-80.

Arif, A., Sugiharto, A. N., \& Widaryanto, E. (2014). Pengaruh umur transplanting benih dan pemberian berbagai macam pupuk nitrogen terhadap pertumbuhan dan hasil tanaman jagung manis (Zea mays L. saccharata Sturt.). Jurnal Produksi Tanaman, 2(1), 1-9.

Batubara, M. H., Niswati, A., Yusnaini, S., \& Arif, M. S. (2013). Pengaruh sistem olah tanah dan aplikasi mulsa bagas terhadap populasi dan biomassa cacing tanah pada pertanaman tebu (Saccharum officinarum L.) tahun ke 2. Jurnal Agrotek Tropika, 1(1), 107-112. 
Cahyani, S., Sudirman, A., \& Azis, A. (2017). Respons pertumbuhan vegetatif tanaman tebu (Saccharum officinarum L.) ratoon 1 terhadap pemberian kombinasi pupuk organik dan pupuk anorganik. Jurnal Agro Industri Perkebunan, 4(2), 69-78.

Desiana, C., Banuwa, I. S., Evizal, R., \& Yusnaini, S. (2013).Pengaruh pupuk organik cair urin sapi dan limbah tahu terhadap pertumbuhan bibit kakao (Theobroma cacao L.). Jurnal Agrotek Tropika, 1(1), 113-119.

Doring T., Heimbach, U., Thieme, T., Finckch, M., \& Saucke, H. (2006). Aspect of straw mulching in organic potatoes-I, effects on microclimate, Phytophtora infestans, and Rhizoctonia solani. Nachrichtenbl. Deut. Pflanzenschutzd, 58(3), 73-78.

Ismayana, A., Indrasti, N. S., Suprihatin, A. M., \& TIP, A. F. (2012). Faktor rasio C/N awal dan laju aerasi pada proses co-composting bagasse dan blotong. Jurnal Teknologi Industri Pertanian, 22(3), 173-179.

Fahrurozzi, H. Bandi dan Latifah. 2005. Perumbuhan dan hasil kedelai pada berbagai dosis mulsa baggase dan pengolahan tanah. Jurnal Akta Agrosia, 8(1): 21-24.

Hamdani, J. S., Suriadinata, Y. R., \& Martins, L. (2016). Pengaruh naungan dan zat pengatur tumbuh terhadap pertumbuhan dan hasil tanaman kentang kultivar atlantik di dataran medium. Jurnal Agronomi Indonesia, 44(1), 33-39.

Kusmayadi, W. (2016). Pengaruh Dosis Bokashi Kirinyuh dan Mulsa Jerami Padi terhadap Pertumbuhan dan Hasil Tanaman Cabai Merah (Capsicum annuum L). UIN Sunan Gunung Djati.

Marliah, A., Nurhayati, \& Susilawati, D. (2009). Pengaruh pemberian mulsa organik terhadap pertumbuhan dan hasil jagung. Jurnal Floratek, 6, 192-201.

Nahnoedin. (1993). Penyedian bibit tebu berkualitas, permasalahan dan penanggulangannya. Gula Indonesia, 15(3), 39-41.

Nurmawati, S. I., Winarni, \& Waskito, A. (2011). Penggunaan mulsa jerami alang-alang dan mulsa baggase pada tanaman tebu. Jurnal Penelitian Matematika, Sains, dan Teknologi, 2, 36-24.

Pantilu, L. I., Mantiri, F. R., Nio, S. A., \& Pandiangan, D. (2012). Respons morfologi dan anatomi kecambah kacang kedelai (Glycine $\max$ (L.) Merill) terhadap intensitas cahaya yang berbeda. BIOSLOGOS, 2(2), 78-87.

Patar, H., Barus, A., \& Irsal, I. (2015). Pengaruh konsentrasi zat pengatur tumbuh dan sumber bud chips terhadap pertumbuhan bibit tebu (Saccharum officinarum) di pottray. Agroekoteknologi, 3(3), 992-1004.

Prasetyo, B. H., \& Suriadikarta, D. A. (2006). Karakteristik, potensi, dan teknologi pengelolaan tanah Ultisol untuk pengembangan pertanian lahan kering di Indonesia. Jurnal Litbang Pertanian, 25(2), 39-46.

Prayogo, S. A., Minwal, M., \& Amir, N. (2016). Pengaruh jenis pupuk organik dan sistem tanam terhadap pertumbuhan bibit tanaman tebu (Saccharum officinarum L.). Klorofil: Jurnal Penelitian Ilmu-Ilmu Pertanian, 11(1), 51-55.

Prayudyaningsih, R., \& Sari, R. (2016). Aplikasi fungi mikoriza arbuskula (FMA) dan kompos untuk meningkatkan pertumbuhan semai (tectona grandis Linn.f.) pada media tanah bekas tambang kapur. Jurnal Penelitian Kehutanan Wallacea, 5(1), 37-46. 
Putra, E., Sudirman, A., \& Indrawati, W. (2017). Pengaruh pupuk organik pada pertumbuhan vegetatif tanaman tebu (Saccharum officinarum L.) varietas GMP 2 dan GMP 3. Jurnal Agro Industri Perkebunan, 4(2), 60-68.

Putri, A. D., Sudiarso, S., \& Islami, T. (2013). Pengaruh komposisi media tanam pada teknik bud chip tiga varietas tebu (Saccharum officinarum L.). Jurnal Produksi Tanaman, 1(1), 16-23.

Ruhnayat, A. (1995). Peranan unsur hara dalam meningkatkan pertumbuhan, hasil, dan daya tahan tanaman tebu. Jurnal Litbang Pertanian, 14(1), 10-15.

Song, A. N., \& Banyo, Y. (2011). Konsentrasi klorofil daun sebagai indikator kekurangan air pada tanaman. Jurnal Ilmiah Sains, 11(2), 166-173.

Sudyastuti, T., \& Setyawan, N. (2007). Sifat thermal tanah pasiran pantai dengan pemberian bahan pengkondisi tanah dan biomikro pada budidaya tanaman cabai (Capsicum Annuum L). Agritech, 27(3), 137-146.

Sukmadjaja, D., Supriyati, Y., \& Pardal, S. J. (2016). Kultur apeks untuk penyediaan bibit unggul tebu varietas PS864 dan PS881. Jurnal AgroBiogen, 10(2), 45-52.

Swibawa, I. G., Yulistiara, S. P., \& Aeny, T. N. (2015). Penerapan sistem olah tanah dan pemulsaan pada tebu untuk pengendalian nematoda parasit tumbuhan dominan. Jurnal Penelitian Pertanian Terapan, 15(2), 115-124.

Windusari, Y., Sari, N. A., Yustian, I., \& Zulkifli, H. (2013). Dugaan cadangan karbon biomassa tumbuhan bawah dan serasah di kawasan suksesi alami pada area pengendapan tailing PT Freeport Indonesia. Biospecies, 5(1), 22-28.

Yunitasari, D., Hakim, D. B., Juanda, B., \& Nurmalina, R. (2015). Menuju swasembada gula nasional: model kebijakan untuk meningkatkan produksi gula dan pendapatan petani tebu di Jawa Timur. Jurnal Ekonomi dan Kebijakan Publik, 6(1), 1-15. 